\title{
PERKEMBANGAN BAYI USIA 6-12 BULAN DENGAN RIWAYAT ASFIKSIA PERINATAL
}

\author{
Ninis Indriani ${ }^{1,2^{*}}$, Yeni Rustina ${ }^{3}$, Nur Agustini ${ }^{3}$
}

1. Sekolah Tinggi Ilmu Kesehatan Banyuwangi, Banyuwangi 68400, Jawa Timur , Indonesia

2. Program Studi Magister Ilmu Keperawatan, Universitas Indonesia, Depok 16424, Indonesia

3. Fakultas Ilmu Keperawatan, Universitas Indonesia, Depok 16424, Indonesia

*E-mail: ninisindriani@gmail.com

\begin{abstract}
Abstrak
Bayi dengan asfiksia perinatal sangat rentan mengalami komplikasi baik jangka pendek seperti disfungsi multiorgan maupun jangka panjang dengan terjadinya gangguan perkembangan. Tujuan penelitian ini adalah untuk mengetahui hubungan riwayat asfiksia perinatal dengan perkembangan bayi usia 6-12 bulan. Desain penelitian menggunakan potong lintang, yang melibatkan 56 bayi dengan riwayat asfiksia perinatal (berat, sedang, dan ringan) di Kabupaten Banyuwangi. Hasil penelitian menunjukkan ada hubungan yang signifikan antara riwayat asfiksia perinatal dengan perkembangan bayi $(\mathrm{p}=0,026)$. Rekomendasi dari penelitian ini adalah perlu melakukan deteksi dini penyimpangan perkembangan khususnya bayi risiko tinggi dan mengoptimalkan peran serta orang tua dalam proses perkembangan anak.
\end{abstract}

Kata kunci: asfiksia perinatal, perkembangan bayi

\begin{abstract}
Development of Infant Age 6-12 Months with History Perinatal Asphyxia. Infant with perinatal asphyxia history is very susceptible to have both short term complications such as multiple organ dysfunctions and long-term complications with development disorder. The purpose of this study is to indentify the correlation between perinatal asphyxia history and infant's development age 6 to 12 months. Design of study used cross sectional, which involves 56 infants with severe, moderate, and mild asphyxia history in Banyuwangi Regency. The result of this study indicates that there is a significant correlation between perinatal asphyxia history and infant's development $(p=0,026)$. The recommendations of this study is that it is necessary to do early detection development disorder especially for high risk infants and optimize the participation of parents in a child's development process.
\end{abstract}

Keywords: infant's development, perinatal asphyxia history

\section{Pendahuluan}

Kematian neonatal dini pada tahun 2010 paling banyak disebabkan oleh asfiksia $(48 \%)$ diikuti oleh prematur (23\%), sepsis dan sindrom gawat napas $(11 \%)$, serta karena kelainan bawaan (9\%). Asfiksia merupakan kegawatan bayi baru lahir yang menyebabkan terjadinya depresi pernapasan serta mengakibatkan komplikasi (Wantania, 2011).

Komplikasi akibat asfiksia perinatal jangka pendek berupa disfungsi multiorgan yang dapat berlanjut kematian, serta komplikasi jangka panjang adalah kelainan neurologi dan keterlambatan perkembangan. Komplikasi ini dapat terjadi karena adanya gangguan pertukaran gas dan pengangkutan oksigen selama persalinan yang dapat memengaruhi fungsi sel organ-organ vital terutama otak yang dapat mengakibatkan kematian atau kecacatan yang ireversibel (Morales, Bustsmante, Marchant, Pena, Manuel, Hernandez, \& Mancilla, 2011). Bayi prematur dengan berat badan lahir rendah (BBLR) berisiko mengalami asfiksia perinatal lebih berat dibandingkan dengan bayi yang lahir aterm (Suradi, Aminullah, Kosim, Rohsiswatmo, Soeroso, Kaban, \&Prasmusinto, 2008).

Sekitar 5-10\% anak mengalami keterlambatan perkembangan dalam dua atau lebih dari aspek perkembangan. Satu sampai tiga persen keterlam- 
batan perkembangan ini terjadi dibawah usia 5 tahun (Cleary \& Green, 2013). Keterlambatan perkembangan dapat terdeteksi secara dini oleh perawat anak. Tindakan yang dapat dilakukan adalah mengidentifikasi bayi yang berisiko mengalami keterlambatan perkembangan, mengikuti perkembangan sejak lahir, serta merencanakan intervensi untuk menghindari masalah yang mungkin timbul. Penelitian Meena, Kurup, dan Ramesh (2013) pada sampel usia neonatal sampai dengan 12 bulan yang berisiko mengalami gangguan perkembangan ditemukan bahwa program intervensi dini dapat meningkatkan perkembangan saraf bayi. Penelitian lain juga menjelaskan bahwa stimulasi perkembangan serta pemberian edukasi pada orang tua dapat mendukung perkembangan anak secara optimal (Tjandrajani,Dewanti, Burhany, \& Widjaja, 2012).

Hasil observasi klinik tumbuh kembang di Kabupaten Banyuwangi (2012) teridentifikasi yaitu 11 anak mengalami perkembangan meragukan dan 8 anak mengalami kemungkinan penyimpangan perkembangan. Pada tahun 2013 terdapat 5 anak mengalami perkembangan meragukan dan 11 anak mengalami kemungkinan penyimpangan perkembangan. Rata-rata anak yang berkunjung ke klinik tumbuh kembang mengalami keterlambatan pada motorik kasar dan gangguan pendengaran.

Penelitian ini dilakukan untuk mengidentifikasi perkembangan bayi usia 6-12 bulan yang mempunyai riwayat asfiksia perinatal. Hal ini penting dilakukan agar perkembangan bayi dapat dicapai dengan optimal dan bayi dapat menjalankan tugas perkembangan sesuai dengan tahap usia.

\section{Metode}

Penelitian ini merupakan penelitian kuantitatif dengan menggunakan desain potong lintang. Teknik pengambilan sampel menggunakan straitifed random sampling dengan jumlah sampel 56 bayi yang berusia 6-12 bulan dengan riwayat asfiksia perinatal yang lahir di salah satu rumah sakit pemerintah di wilayah Kabupaten Banyuwangi yang memenuhi kriteria inklusi yaitu tidak memiliki kelainan kongenital.
Alat pengumpul data untuk mengukur perkembangan bayi menggunakan formulir kuesioner pra skrining perkembangan (KPSP) untuk bayi usia 6 bulan, 9 bulan, dan 12 bulan, sedangkan untuk instrumen stimulasi perkembangan, peneliti melakukan modifikasi instrumen yang diambil dari buku pedoman pelaksanaan stimulasi, deteksi dan intervensi dini tumbuh kembang anak di tingkat pelayanan kesehatan dasar (SDIDTK). Uji validitas instrumen menggunakan uji korelasi product moment dengan hasil nilai $r$ hitung lebih besar dari $r$ tabel, sehingga disimpulkan bahwa pertanyaan dalam kuesioner tersebut valid. Uji reliabilitas instrumen menggunakan koefisien Cronbach alpha dan didapatkan nilai koefisien sebesar 0,92 dan 0,90 yang menunjukkan kedua instrumen tersebut dinyatakan reliabel.

Untuk menyamakan persepsi dalam menggunakan formulir KPSP dilakukan uji inter-rater reliability. Hasil uji korelasi Kappa adalah 0,000 yang menunjukkan bahwa terdapat persepsi yang sama antara peneliti dengan asisten peneliti. Analisis data menggunakan program komputer untuk analisis univariat dan bivariat. Analisis univariat digunakan untuk variabel karakteristik responden (jenis kelamin, usia gestasi, jenis persalinan, berat badan saat lahir, dan status gizi) dan karakteristik orang tua responden (jumlah anak, status pekerjaan ibu, pendidikan orang tua, status ekonomi, dan stimulasi yang diberikan orang tua kepada bayi). Analisis bivariat digunakan untuk melihat adanya korelasi dengan uji Spearman dan Lamda.

\section{Hasil}

Karakteristik responden penelitian berdasarkan jenis kelamin menunjukkan jumlah yang hampir seimbang antara laki-laki dan perempuan, dengan jenis persalinan paling banyak adalah jenis persalinan spontan yaitu 50,0\%. Sebagian besar responden berstatus gizi baik yaitu sebesar $91,1 \%$. Berdasarkan usia gestasi, rerata usia gestasi responden adalah 37,84 minggu, usia gestasi responden termuda adalah 31 minggu dan usia gestasi responden tertua adalah 43 minggu, sedangkan berdasarkan berat badan saat lahir didapatkan rerata adalah 2933,04 gram. Berat badan respon- 
den terendah adalah 1800 gram dan berat badan responden tertinggi adalah 4500 gram.

Karakteristik orang tua responden pada penelitian ini adalah sebagian besar memiliki jumlah anak sebanyak 2 orang, dengan latar belakang pendidikan mayoritas SLTA, status pekerjaan ibu paling banyak adalah tidak bekerja dan sebagian besar berstatus sosial ekonomi atas. Berdasarkan stimulasi yang diberikan pada bayi, sebagian orang tua jarang memberikan stimulasi kepada bayi mereka.

Tabel 1 menjelaskan bahwa perkembangan bayi dengan riwayat asfiksia perinatal sebagian besar mempunyai perkembangan yang sesuai dengan usia, yaitu $46,4 \%$. Persentase tersebut lebih tinggi daripada bayi yang mengalami kemungkinan penyimpangan perkembangan (14,3\%). Tabel 2 menggambarkan adanya hubungan yang bermakna antara riwayat asfiksia perinatal dan perkembangan bayi $(p=0,026 ; \alpha=0,05)$.

Hasil analisis antara riwayat asfiksia perinatal dengan karakteristik responden dan orang tua responden menunjukkan bahwa variabel usia gestasi, berat badan saat lahir, tingkat pendidikan orang tua dan pemberian stimulasi mempunyai hubungan yang bermakna dengan perkembangan

Tabel 1. Karakteristik Responden berdasarkan Perkembangan Bayi

\begin{tabular}{lcc}
\hline \multicolumn{1}{c}{ Kriteria } & $\begin{array}{c}\text { Frekuensi } \\
(\mathbf{n})\end{array}$ & $\begin{array}{c}\text { Prosentase } \\
(\boldsymbol{\%})\end{array}$ \\
\hline Kemungkinan menyimpang & 8 & 14,3 \\
Meragukan & 22 & 39,3 \\
Sesuai & 26 & 46,4 \\
\hline
\end{tabular}

Tabel 2. Hubungan Riwayat Asfiksia Perinatal dengan Perkembangan Bayi

\begin{tabular}{lccccccc}
\hline \multirow{2}{*}{$\begin{array}{l}\text { Jenis } \\
\text { Asfiksia }\end{array}$} & \multicolumn{9}{c}{ Merkembangan } & & \\
\cline { 2 - 6 } & $\mathbf{n}$ & $\%$ & $\mathbf{n}$ & $\%$ & $\mathbf{n}$ & $\%$ & \\
\hline $\begin{array}{l}\text { Asfiksia } \\
\text { ringan }\end{array}$ & 3 & 27,3 & 5 & 45,5 & 3 & 27,3 & 0,026 \\
$\begin{array}{l}\text { Asfiksia } \\
\text { sedang }\end{array}$ & 2 & 11,1 & 10 & 55,6 & 6 & 33,3 & \\
$\begin{array}{l}\text { Asfiksia } \\
\text { berat }\end{array}$ & 3 & 11,1 & 7 & 25,9 & 17 & 63,0 & \\
\hline
\end{tabular}

Tabel 3. Hubungan Karakteristik Responden dan Orang Tua Responden dengan Perkembangan Bayi

\begin{tabular}{lcc}
\hline \multicolumn{1}{c}{ Parameter } & Nilai Korelasi (r) & p \\
\hline Jenis kelamin & 0,033 & 0,841 \\
Usia gestasi & 0,314 & 0,018 \\
Jenis Persalian & 0,100 & 0,465 \\
Status gizi bayi & 0,053 & 0,697 \\
Berat badan saat lahir & 0,280 & 0,037 \\
Pendidkan orang tua & 0,401 & 0,002 \\
Jumlah anak & 0,029 & 0,919 \\
Pekerjaan ibu & 0,251 & 0,062 \\
Status sosial ekonomi & 0,084 & 0,538 \\
Stimulasi & 0,329 & 0,013 \\
\hline
\end{tabular}

bayi, sedangkan variabel jenis kelamin, jenis persalinan, status gizi bayi, jumlah anak, status pekerjaan ibu, dan status sosial ekonomi tidak mempunyai hubungan yang bermakna dengan perkembangan bayi. Hasil analisis korelasi antara karakteristik responden dan orang tua responden dengan perkembangan bayi dipaparkan pada Tabel 3.

\section{Pembahasan}

Hasil penelitian menunjukkan bahwa ada hubungan antara kelahiran asfiksia dengan perkembangan bayi. Hasil penelitian ini didukung oleh penelitian Resegue, Puccini, dan Silva (2008) yang menyatakan bahwa bayi dengan asfiksia perinatal mempunyai risiko untuk mengalami kesakitan yang tinggi. Kerusakan otak pada bayi asfiksia dianggap sebagai penyebab utama terjadinya gangguan perkembangan. Penelitian lain juga menjelaskan bahwa asfiksia perinatal merupakan penyebab terjadinya Attention Deficit Hyperactivity Disorder (ADHD), dan kejadian ADHD lebih banyak ditemukan pada anak dengan riwayat skor APGAR yang rendah (Willcutt, 2007). Bayi dengan asfiksia perinatal apabila mampu beradaptasi dengan lingkungan ekstrauterin akan mampu melewati perkembangan bayi selanjutnya (Tomey \& Alligood, 2010). Kerusakan otak bayi dengan asfiksia perinatal mengancam integritas struktur bayi yang dapat mengganggu perkembangan bayi selanjutnya. Intervensi yang bisa dilakukan untuk mencegah terjadinya gangguan perkembangan diantaranya adalah dengan mencegah terjadinya 
faktor risiko asfiksia perinatal yaitu dengan menghindari terjadinya penyulit persalinan, dan penanganan bayi asfiksia perinatal dengan cepat dan tepat sehingga ancaman terjadinya gangguan perkembangan dapat diminimalkan.

Hasil penelitian ini menunjukkan tidak ada hubungan antara jenis kelamin dengan perkembangan bayi. Hasil penelitian ini selaras dengan yang dilakukan Nayeri, et al., (2010) yang menjelaskan bahwa tidak ada perbedaan pada perkembangan antara bayi laki-laki dan perempuan. Menurut Kementerian Kesehatan Republik Indonesia (2010), perkembangan antara laki-laki dan perempuan perbedaannya terletak pada kecepatan pertumbuhan secara fisik. Anak perempuan lebih cepat tumbuh dan berkembang, serta lebih cepat mencapai kedewasaan jika dibandingkan dengan laki-laki.

Hasil analisis antara usia gestasi dengan perkembangan bayi didapatkan terdapat korelasi yang bermakna. Salah satu penelitian menjelaskan bahwa prematur dapat menyebabkan beberapa gangguan perkembangan diantaranya terjadinya serebral palsi; retardasi mental; gangguan sensori seperti terjadinya gangguan pendengaran dan penglihatan; disfungsi otak seperti gangguan bahasa dan kemampuan belajar, hiperaktivitas, kurang perhatian, serta adanya gangguan perilaku (Kosim, 2006).

Hasil analisis antara variabel jenis persalinan dengan perkembangan bayi diketahui tidak ada hubungan yang signifikan. Hal ini sesuai dengan penelitian yang dilakukan Islam, Khan, dan Murtaza (2008) yang menyatakan bahwa perkembangan bayi yang lahir dengan vakum menunjukkan tidak ada pengaruh yang signifikan. Vakum ekstraksi membantu pengeluaran bayi dengan memberikan tekanan negatif dan mempermudah tarikan saat ibu mengejan dan hal ini tidak mengganggu perkembangan bayi selanjutnya.

Hubungan yang bermakna juga ditemukan pada penelitian ini antara variabel berat badan saat lahir dan perkembangan bayi. Shabliz dan Kianian (2014) menjelaskan bahwa terdapat perbedaan yang signifikan pada hasil tes Inteleqtual Quotient (IQ) pada kelompok berat badan lahir normal dengan kelompok BBLR dimana kelompok BBLR mayoritas memiliki tingkat IQ lebih rendah dibandingkan dengan kelompok bayi lahir normal. Selain itu ditemukan juga bahwa BBLR secara tidak langsung berhubungan dengan terjadinya retardasi mental.

Hasil analisis menunjukkan tidak ada hubungan bermakna antara status gizi dan perkembangan anak. Hasil penelitian ini didukung penelitian yang dilakukan oleh Gunawan, Fadlyana, dan Rusmil (2011) yang menyatakan bahwa tidak ada hubungan antara gangguan perkembangan dan status gizi anak, responden penelitian berusia 1-2 tahun dan berada dibawah pengawasan ibunya, sehingga mendapatkan stimulasi yang adekuat. Dalam penelitian ini sebagian besar dari responden mempunyai status gizi yang cukup baik. Hal ini diasumsikan bahwa anak usia dibawah 12 bulan mayoritas masih mendapatkan perhatian dari segi makanan serta masih mendapatkan ASI dari ibunya.

Jumlah anak dalam keluarga dapat menentukan perkembangan seorang anak. Pada penelitian ini rerata jumlah anak dalam keluarga memiliki 2 sampai 3 anak; sedangkan hasil analisis bivariat dalam penelitian ini menunjukkan tidak adanya hubungan bermakna antara jumlah anak dan perkembangan anak. Menurut Okzan, Senel, Arslan, dan Karacan (2012) keluarga dengan anak lebih dari 3 orang menyebabkan kualitas dalam pengasuhan kurang maksimal karena waktu yang tidak optimal untuk setiap anak. Namun demikian, meskipun jumlah anak dari masing-masing keluarga lebih dari 3 orang, tetapi karena kebanyakan para ibu responden sebagai ibu rumah tangga maka setiap saat ada bersama dengan anak serta memiliki waktu yang cukup untuk mengasuh anak dan masih tetap bisa berinteraksi dengan anak. Oleh karena itu jumlah anak 2-3 orang tidak berdampak terhadap perkembangan anak.

Hasil penelitian ini menunjukkan bahwa tingkat pendidikan orang tua paling banyak adalah SLTA $(37,5 \%)$ dan hasil analisis bivariat menunjukkan tidak adanya hubungan antara tingkat pendidikan 
orang tua dengan perkembangan anak. Hal ini dapat disebabkan karena mayoritas pendidikan orang tua responden adalah SLTA. Hal lain yang dapat dijelaskan adalah tingkat pendidikan orang tua yang SLTA diasumsikan mampu mencari informasi baik melalui media cetak maupun televisi serta mampu menerima informasi yang diberikan oleh tenaga kesehatan tentang pola asuh yang benar dan cukup baik untuk memberikan pendidikan dini melalui stimulasi yang diberikan kepada anak.

Hasil analisis status pekerjaan ibu terhadap perkembangan anak dinyatakan tidak ada hubungan yang signifikan. Hal ini bisa disebabkan rerata ibu responden tidak bekerja sehingga para ibu setiap saat dapat berinteraksi dengan bayi serta memiliki waktu penuh untuk mengasuh anak. Menurut Lindawati (2013) ibu yang bekerja tidak mempunyai pengaruh terhadap pertumbuhan dan perkembangan anak. Hal ini dimungkinkan terjadi karena pendidikan ibu yang bekerja lebih tinggi atau lebih banyak terpapar informasi sehingga ibu dapat mengantisipasi segala kemungkinan yang dapat terjadi ketika anak ditinggal bekerja.

Pada penelitian ini tidak ditemukan adanya hubungan yang bermakna antara status sosial ekonomi dan perkembangan anak. Hal ini dimungkinkan karena rerata responden berasal dari keluarga dengan status sosial ekonomi menengah ke atas, sehingga pola pengasuhan terhadap anak cukup baik. Disamping itu, faktor sosial ekonomi juga merupakan salah satu faktor lingkungan yang dapat memengaruhi perkembangan anak. Orang tua responden yang berasal dari status sosial ekonomi atas dapat menyediakan makanan yang bergizi serta mampu menyediakan alat bantu yang memadai untuk memberikan stimulasi pada anak.

Stimulasi dari lingkungan dalam hal ini orang tua sebagai orang yang terdekat dengan anak sangat mendukung tercapainya perkembangan anak yang optimal. Stimulasi sebaiknya dilakukan sedini mungkin sejak dalam kandungan (Suryawan \& Irwanto, 2009). Pada penelitian ini didapatkan ada hubungan antara pemberian stimulasi dan perkembangan bayi. Hal ini sesuai dengan per- nyataan sebelumnya yang menjelaskan bahwa stimulasi sangat penting untuk perkembangan anak. Anak yang mendapatkan stimulasi yang benar dan teratur akan lebih cepat berkembang dibandingkan dengan anak yang tidak atau kurang mendapatkan stimulasi dari orang tuanya.

Implikasi penelitian bagi pelayanan keperawatan adalah perawat dapat menghindari faktor risiko terjadinya asfiksia perinatal. Selain itu penolong persalinan juga harus mempunyai keterampilan dalam menangani kelahiran bayi dan memfasilitasi proses adaptasi bayi dari lingkungan intrauterin ke ekstrauterin secara optimal, sehingga asfiksia dapat dihindari. Petugas kesehatan sangat perlu melakukan pemantauan pertumbuhan dan perkembangan anak, terutama pada bayi yang lahir dengan risiko keterlambatan perkembangan. Sosialisasi pentingnya stimulasi dan cara pemberian stimulasi yang benar oleh perawat perlu ditingkatkan, sehingga perawat mampu mengedukasi orang tua tentang pentingnya stimulasi tumbuh kembang anak.

\section{Kesimpulan}

Hasil penelitian yang dilakukan pada 56 responden ini menunjukkan hasil bahwa jumlah jenis kelamin yang seimbang antara laki-laki dan perempuan, dengan jenis persalinan paling banyak adalah spontan, mayoritas bayi berstatus gizi baik, rerata usia gestasi 37,84 minggu dan berat badan rerata 2933 gram. Karakteristik orang tua responden mayoritas mempunyai anak 2 sampai dengan 3 orang, dengan latar belakang pendidikan paling banyak adalah SLTA, ibu berstatus tidak bekerja dengan mayoritas tingkat status sosial ekonomi atas dan kebanyakan orang tua jarang memberikan stimulasi kepada anak.

Mayoritas perkembangan bayi adalah sesuai dengan usia. Berdasarkan uji statistik bivariat didapatkan bahwa ada hubungan antara riwayat asfiksia perinatal dengan perkembangan bayi usia 6 sampai 12 bulan. Variabel perancu yang memiliki korelasi dengan perkembangan bayi diantaranya adalah usia gestasi, berat bayi saat lahir, pendidikan orang tua, serta pemberian stimulasi orang tua kepada anak. 
Rekomendasi penelitian khususnya untuk perawat anak adalah diharapkan mampu melakukan deteksi dini bayi yang berisiko mengalami gangguan perkembangan serta mampu bekerjasama dengan perawat komunitas dalam mensosialisasikan tahap perkembangan anak sesuai usia kepada masyarakat $(\mathrm{NN}, \mathrm{INR}, \mathrm{PN})$

\section{Referensi}

Cleary, M.A., \& Green, A. (2013). Developmental delay: When to suspect and how to investigate for an inborn error of metabolism. Archives of Disease in Childhood, 90(11), 1128-1132.

Depkes RI. (2009). Sistem kesehatan nasional. Jakarta: Departemen Kesehatan Republik Indonesia

Gunawan, G., Fadlyana, E., \& Rusmil, K. (2011). Hubungan status gizi dan perkembangan anak usia 1-2 tahun. Sari Pediatri, 13(2), 142-146.

Islam, A., Khan, A.H., \& Murtaza. (2008). Vacuum extraction and forceps deliveries; comparison of maternal and neonatal complication. Professional Med J, 15(1), 87-90.

Kementerian Kesehatan RI. (2010). Pedoman pelaksanaan stimulasi, deteksi dan intervensi dini tumbuh kembang anak ditingkat pelayanan kesehatan dasar. Jakarta: Departemen Kesehatan republik Indonesia.

Kosim, M.S. (2006). Gawat darurat neonatus pada persalinan preterm. Sari Pediatri, 7(4), 225-231.

Lindawati. (2013). Faktor-faktor yang mempengaruhi perkembangan motorik anak usia pra sekolah. Jurnal Health Quality, 4(1), 22-27.

Meena, N., Kurup, V.K.M., \& Ramesh, S. (2013). Impact of early intervention in the developmental outcome of infants with birth asphyxia. Indian Journal of Applied Research, 3(3), 301-304.

Morales, P., Bustamante, D., Marchant, P.E., Peña, T.N., Hernández, M.A.G., Castro, C.A., \&
Mancilla, E.R. (2011). Pathophysiology of perinatal asphyxia: Can we predict and improve individual outcome? EPMA Journal, 2(2), 211-230.

Nayeri, F., Shariat, M., Dalili, H., Adam, L.B., Mehrjerdi, F.Z., \& Shakeri, A. (2012). Perinatal risk factor neonatal asphyxia in Vali-e-Asr Hospital, Tehran Iran. Iran J Reprod Med, 10(2), 137-140.

Okzan, M., Senel, S., Arslan, E.A., \& Karacan, C. D. (2012). The socioeconomic and biological risk factor for developmental delay in early childhood. Eur J Pediatr, $171,1815-1821$.

Resegue, R., Puccini, R.F., \& Silva, E.M.K. (2008). Risk factors associated with developmental abnormalities among high-risk children attended at a multidisciplinary clinic. San Paulo Med J, 126(1), 4-10.

Shabliz, M.S., \& Kianian, E. (2014). The relationship between child's birth weight and mental retardation among low-weight children. International Journal of Academic Research in Business and Social Sciences, 4(1), 592-599.

Suradi, R., Aminullah, A., Kosim, S., Rohsiswatmo, R., Soeroso, S., Kaban, R., \& Prasmusinto, D. (2008). Pencegahan dan penatalaksanaan asfiksia neonaturum. Jakarta: Departemen Kesehatan Republik Indonesia.

Suryawan, A., \& Irwanto. (2009). Deteksi dini tanda dan gejala penyimpangan partumbuhan dan perkembangan anak. Surabaya: IDAI Jawa Timur.

Tjandrajani, A., Dewanti, A., Burhany, A., \& Widjaja, J.A. (2012). Keluhan utama pada keterlambatan perkembangan umum di klinik khusus tumbuh kembang RSAB Harapan Kita. Sari Pediatri, 13(6), 373377.

Tomey, A.M., \& Alligood, M.R. (2010). Nursing theorists and their work (7th Ed.). St Louis: Mosby Elsevier.

Wantania, J., Wilar, R., Antolis, R., \& Mamangkey, G. (2011). Faktor risiko 
kehamilan dan persalinan yang berhubungan dengan kematian neonatal dini di RSU Prof. R. D. Kandou Manado. Buletin Perinasia, 3, 1-10.
Willcutt, E. (2007). The etitlogy of $G P P / H$. London: Oxford University Press. 